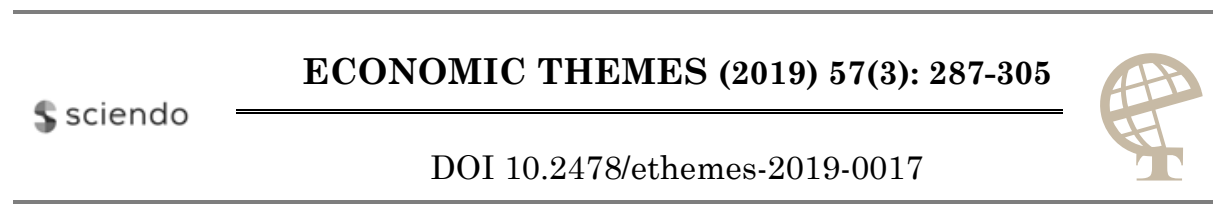

\title{
THE IMPACT OF ECONOMIC REFORMS ON POVERTY IN THE REPUBLIC OF SERBIA
}

\author{
Nevena Veselinović \\ Faculty of management Zaječar, Republic of Serbia \\ $\bowtie$ nveselinovicc@gmail.com \\ Ivan Mišić \\ Serbian Army General Staff \\ $\bowtie$ musculusivan@hotmail.com \\ Petar Veselinović \\ Faculty of Economics, University of Kragujevac, Republic of Serbia \\ $\bowtie$ pveselinovic@kg.ac.rs
}

UDC

338.2 :

364.662

(497.11)

Original

scientific

paper

Received:

05.09.2019

Accepted:

28.11.2019

\begin{abstract}
The aim of the paper is to identify the key determinants of poverty in the Republic of Serbia. The secondary goal is to show that poverty can be reduced if the classic concept of treating poverty is abandoned and the concept of social exclusion accepted, the benefits of which are to look at causes and provide a basis for preventing the problem of poverty, rather than just attempting to remedy the consequences. In the paper, statistical-econometric models are applied which correspond to the defined goal of the empirical research, but also to the selected variables. Part of the data analysis was carried out on data collected through the Survey on Income and Living Conditions (EU-SILC). It is an instrument that is among the most relevant when it comes to monitoring poverty, inequality, social inclusion and living standards. The contribution of work is reflected in the development of the poverty research in the Republic of Serbia with the aim of complementing the scientific knowledge fund on the implementation of state measures and instruments in the context of stimulating economic growth and increasing the living standard of the population.
\end{abstract}

Keywords: transition, poverty, living standard, Republic of Serbia

JEL classification: E16, E24 


\section{Introduction}

The subject of research is the analysis of poverty, its causes, conditions and trends in the Republic of Serbia. Poverty is not just viewed here as a lack of material goods, which is the essence of a conventional view of poverty. The question should not be so much focused on whether the decline in production and the increase in inequality has increased poverty - because the answer is unequivocally confirmed rather than why this reduction was so pronounced in the Republic of Serbia, and in other transition countries, why not inequality followed such a different pattern. Apart from the determinants of production and income, the most important factors were the type and quality of economic reforms that countries decided to implement. There is a close connection between deep reforms and economic success. Analysts, however, state that other factors are important: initial conditions (including accommodation, initial economic situation and natural resources); the institutional situation at the beginning of the transition, as well as the political system. These factors also have a direct and strong impact on the product achieved. At the same time, these non-political factors have a decisive influence on the choice of reforms and on the extent to which countries are able to implement them.

Each of these factors influences the distribution of income and consumption, and consequently the level of poverty, independently of others. While economic growth is crucial for combating poverty, it must not be lost in view of the change in the distribution of income, which is accompanied by this growth. Namely, the effect of economic growth on poverty depends on how the additional income, which generates growth, is distributed among members of society. If economic growth is accompanied by an increase in the share of the poor in income distribution, then the incomes of this category of population will grow faster than average income and vice versa. The same applies to the poverty rate.

The transition in Serbia took place quite slowly, with great difficulties and stalemates. Only recently, with Serbia's emergence from long-standing economic and political isolation, conditions have been created for intensifying market reforms and initiating economic development on a sound and stable basis. The fate of poverty in the process of economic reforms depends largely on economic growth, and this is how economic reforms are shaped and implemented. Economic growth is a powerful means of combating poverty, as evidenced by recent empirical research. Therefore, it is vitally important for Serbia, as well as other countries in transition, to ensure a sustainable and dynamic increase in real income. 


\section{Literature review}

\subsection{Economic growth in the period of transition of the Serbian economy}

The general definition of the transition process is that it is a transition from a nonmarket form to a market-based form of business. This definition does not cause controversy. However, as soon as it goes beyond its practical application, there are innumerable dilemmas: about the way in which the transition from one state to another, about the distribution of the costs of induced changes and the time sequence of the changes. This is understandable because these dilemmas reflect the interests of individual groups.

Blanchard (2007) defines the transition through the key elements of this process, such as: privatization of state / social enterprises; restructuring of large public enterprises; establishment of the market of goods, services and factors of production; reform of social institutions; reform of the social security system.

The experience of transition countries suggests that the speed, and even the effectiveness of the restructuring process, largely depends on the structure of the owners, although the experience varies considerably from enterprise to enterprise, and from country to country, however, in general, the concentration of ownership and the special introduction of foreign investors has a strong positive effect on the restructuring of the business.

One of the main needs of transition is to look at the vision of the economic system to which it is striving, as well as the choice of the model of privatization that leads to the realization of this vision. Previous experience shows that the best results have been achieved by the economies relied on the model of takeovers by the employees in the choice of the privatization model, as well as models of sales to strategic partners. The application of the above-mentioned models leads to entrepreneurial and liberal capitalism (Cerović, 2003).

The fact is that transition in Serbia is delayed, especially in comparison with the achieved degree of development of transition in other former socialist countries. For almost a decade, the delay in reform processes has certainly affected the flow and results of transition.

Macroeconomic developments in Serbia at the beginning of the 21 st century are characterized by an increase in economic activity, a significant reduction in inflation, a high unemployment rate, faster growth in wages from productivity growth, an increase in imports and exports with a high deficit in the trade balance, as well as accelerating privatization, implementing market reforms and initiating accession to the European Union, which includes adapting a variety of legal and other regulations in all areas of economic and social life. Today the Serbian economy is at a great turning point. The first phase of the implementation of the 
transition processes is over, the reform processes get a new momentum, and the future in Euro-Atlantic integration becomes more and more certain. In Serbia, a flexible and strong macroeconomic basis has not yet been created, which would send clear signals to the microeconomic level, which is the basic precondition for sustainable growth of employment, exports, investments and domestic savings.

When it comes to the concept of economic reforms, one should bear in mind the circumstances that it did not take place with the existence of a clear and comprehensive vision. In addition, during the entire reform period, the number of poor people rose, constantly followed by the decline in their standard of living. Transitional economies in Southeast Europe have been "overheated" for many years, facing increasing current account deficits, with increasing indebtedness and unbalanced exchange rates. Namely, the cyclical movement of production, employment and prices, as well as the accompanying phenomenon of economic fluctuations, point to, among other things, that economic growth is not a linear process, but exclusively occurs at intervals by expressing, in the most varied changes in the structure of the economy (Đorđević\&Obradović, 2012). The transition process proved to be more complicated and longer-term than the original expectations. It turned out that the idea of a rapid transition was ignored by a large number of circumstances related to the ability of national economies to complete the reforms within the foreseen deadline, among other things, the question of how economies in transition will react to the emergence of cyclical movements, above all the onset of recession and crisis.

Serbia is lagging behind in reform processes, especially in key segments: privatization and restructuring of large enterprises, competition policy and institutional reforms. The acceleration of reforms that followed after 2000 was short-lived, and Serbia's economy quickly faced the global economic crisis, insufficiently prepared and trained for challenges of this kind, which caused negative tendencies in most microeconomic indicators.

Table 1. GDP growth in $\%$

\begin{tabular}{|c|c|c|c|c|c|c|c|c|c|c|}
\hline \hline & 2008 & 2009 & 2010 & 2011 & 2012 & 2013 & 2014 & 2015 & 2016 & 2017 \\
\hline $\begin{array}{c}\text { Real GDP growth } \\
\text { (in\%) }\end{array}$ & 5,4 & $-3,1$ & 0,6 & 1,4 & $-1,0$ & 2,6 & $-1,8$ & 0,8 & 2,8 & 1,9 \\
\hline $\begin{array}{c}\text { Consumerprices } \\
\text { in\% compared to } \\
\text { the same month of } \\
\text { the previousyear) }\end{array}$ & 8,6 & 6,6 & 10,3 & 7,0 & 12,2 & 2,2 & 1,7 & 1,5 & 1,6 & 3,0 \\
\hline
\end{tabular}

Source: Statistical Office of the Republic of Serbia, Economic Trends in the Republic of Serbia

A high rate of economic growth, achieved after 2000, was obtained with a high rate of inflation, a high foreign trade deficit in the balance of payments, a high 
level of public debt, and a high unemployment rate for the working-age population. All this indicates that the quality of economic growth is not satisfactory, as it was based on the growth of domestic consumption and imports, and that institutional reforms and economic policy were not sufficiently effective in the first decade of the 21 st century.

In the first eight years of implementation of reforms, Serbia achieved a relatively high average annual rate of real GDP growth and cumulative growth of gross domestic product, which is a significant result of economic policy achieved in the conditions of transition and cyclical movements of the world economy. Economic growth was predominantly driven by domestic demand and exports. Investments and structural reforms, primarily the privatization of social enterprises, have been positive for growth. However, it should be noted that the relatively high rates of economic growth are owed to the low start-up base that the Serbian economy had in the years before the beginning of the implementation of the reforms.

\subsection{Poverty trends in the Republic of Serbia}

Poverty exists in a particular society when one or more persons cannot reach the level of economic well-being considered to be an acceptable minimum according to the standards of a given society (Townsend, 2010). This definition indicates that the concept of poverty is determined by the norms, values and circumstances that prevail in society. If we are to rely on this definition, it would be difficult to make comparisons between countries and societies because the nature and structure of poverty can vary from one society to another.

The concept and meaning of poverty can also be defined as "economic deprivation". Economic deprivation denotes the lack of economic resources (available cash or other form of liquid assets) of an individual or household, necessary for the consumption or purchase of economic goods such as food, housing, clothing and footwear. The poverty threshold is carried out using the available economic resources of the household or their actual consumption which is required to meet the minimum standard living. The concept of poverty, by definition, relates exclusively to a narrowly defined economic deprivation, there are many forms of deprivation in society - from those psychological, physical, social, whose elements do not go into poverty indicators (Silver, 2004). Poverty indicators are narrowly oriented to the examination of the material situation, i.e. economic or material poverty of the household or individual. The inability to include other forms of deprivation in the indicators of economic poverty is a basic lack of indicators of poverty, and a new methodology and indicators are needed to follow the trend of moving the standard of living towards other forms of deprivation in society. 
Measurement of poverty is of great importance because it allows us to see the dimensions and understand the problem of poverty in one country and how to alleviate or eliminate poverty. In order to monitor the movement of poverty over time and compare it with other countries, it is necessary to conduct an adequate poverty analysis. Such an analysis should give us answers to very important questions about the number of poor and the depth of their poverty, who is poor (according to gender, age, region, education, etc.) and why they are poor. In order to make sense of this analysis sense and be credible, it is necessary to take the overall poverty indicator, that is, a quantitative measure that will separate the poor from those who are not. As two common types, that is, the method of measuring poverty, the absolute and relative poverty lines are listed.

The concept of absolute poverty starts from a reasonable idea that poverty means a low level of possession of goods and services by individuals, so low that he fails to meet his basic needs (Begović et al, 2009). This should mean that anyone who is below the poverty line, according to a predetermined indicator, will be considered poor. As indicators, that is, quantitative measures can be taken: food, housing, clothing, footwear, basic hygiene products, drugs and the like. However, all these indicators need to be aggregated into one synthetically so that the whole analysis and comparison make sense. As a common content provider that is easily accessible, their monetary value is taken. This kind of synthetic indicator facilitates the identification of the poverty line, the counting and the calculation of the depth of their poverty.

"Absolute" does not mean fixed in time, nor is it the same for all societies. The absolute poverty line, therefore, varies according to the various physiological, social and economic demands of different countries. Although poverty lines vary from country to country and over time, they are all based on an absolute picture of the ability to function in society. After determining the indicator on the basis of which poverty will be assessed, it is necessary to collect data on the income and expenditure of households and individuals. This is done on the basis of the Living Standards and Measurement Survey (LSMS) developed by the World Bank.

Finally, it is necessary to establish a poverty line, where there is no objective methodology for its identification. This is done by some professional standards and economic methods. For example, nutrition is based on nutritional standards of healthy food, such as the required number of calories, essential vitamins, proteins and minerals. The dwelling takes the minimum space required for one household member. Costa (2006) states that an absolute poverty line can be an external poverty and a general poverty line. The external (nutritional, primary) poverty or "misery" line is determined based on the value of the food package. The general (secondary) poor are those who cannot meet all basic needs or use ineffective resources otherwise. 
The relative poverty line is used in some countries where one segment of the population by income or consumption is declared as the poor, without attempting to establish the poverty line objectively (Begović et al, 2009). In European countries, poor people are those whose income is lower than half of the median income, which is always lower than the average. Such a poverty line is very suitable for directing social policy programs towards the poor, but does not show a real number of poor people. So, this is a different approach to the problem, because the idea of poverty is gained by comparing it with others. From the point of view of income, the individual is poor if he belongs to the lower income group. Since some members of society are always in a worse position than others, relative poverty cannot be eradicated (Costa, 2006). The disadvantages of this method for measuring poverty are reflected in the fact that poverty does not depend on economic development, so a certain country can develop at exceptional rates of growth and thus income to the poor to increase at the same rates, but their number will not change at all. On the other hand, there may be a reduction in the number of poor people even if there is no economic growth at all, but there is a decrease in inequality through redistributive actions.

Poverty, which occurred in Serbia during the transition period, cannot be explained by the process of transition, as is the case with other former socialist countries. It is known that the transition in Serbia took place quite slowly, with great difficulty and congestion. Only recently, with Serbia's emergence from longstanding economic and political isolation, conditions have been created for intensifying market reforms and initiating economic development on a sound and stable basis. The fate of poverty in the process of economic reforms depends largely on economic growth, and this is how economic reforms are shaped and implemented. Economic growth is a powerful means of combating poverty, as confirmed by empirical research (Dollar\&Kraay, 2010). Therefore, it is vitally important for Serbia, as well as other countries in transition, to ensure a sustainable and dynamic increase in real per capita income.

The rate of economic growth and the rate at which growth is transformed into poverty reduction is not simply a matter of choice, but a product of a complex set of interactions between the initial condition characteristics of one country, its institutions, the policies pursued, the external shocks to which it is exposed, and the dose of happiness that is followed. Some economic policies undoubtedly favor economic growth. Openness to international exchange, sound monetary and fiscal policy (characterized by a moderate budget deficit and absence of high inflation), with a well-developed financial system and an optimum dimensioned country, strongly contribute to the increase in production. Institutional factors are also important. It turned out that the rule of law and the absence of corruption have a positive effect on economic expansion, creating a favorable environment, based on rules, for investment and economic advancement (Devetaković et al, 2008). 
While economic growth is crucial for combating poverty, it must not be left considering the change in income distribution, which is accompanied by this growth. Veselinovic (2013) points out that the effect of economic growth on poverty depends on how the additional income, which is generated, is distributed among members of society. If economic growth is accompanied by an increase in the share of the poor in income distribution, then the incomes of this category of population will grow faster than the average income and vice versa. The same applies to the poverty rate. At a given pace of economic growth, poverty will fall faster if income distribution is balanced than if it becomes more uneven.

The poverty line in 2016 is 11,694 dinars per month per consumer unit and is the result of a regular annual adjustment for the amount of inflation since 2006 when the line was originally set. Every person who has monthly spending below this amount falls into the category of absolutely poor people.

Within households, the allocation and sharingof resources are assumed, so that each subsequent adult in the household, according to the OECD scale of equivalences, "consumes" 0.7 of the amount an adult would "spend" living alone. For a child under the age of 14 , a weight of 0.5 is applied. For example, a household with four members (two adults and two children under 14 years of age) in 2016 is considered poor if it has a monthly consumption of less than 31,574 dinars (Mijatović, 2017).

In the entire observed period 2006-2016. It is not possible to talk about a significant reduction in the poverty rate. In the last observed 2016, 7.3\% of the population is absolutely poor, while the decrease in the absolute number of the poor is primarily a result of a decrease in the number of inhabitants. Approximately half a million inhabitants do not have enough energy to cover basic living needs.

Table 2.Poverty rate, 2006-2016. Years

\begin{tabular}{|c|c|c|c|c|c|c|c|c|c||}
\hline & 2008. & 2009. & 2010. & 2011. & 2012. & 2013. & 2014. & 2015. & 2016. \\
\hline $\begin{array}{c}\text { Poverty } \\
\text { rates }\end{array}$ & 6,1 & 6,6 & 7,6 & 6,6 & 6,3 & 7,4 & 7,6 & 7,4 & 7,3 \\
\hline
\end{tabular}

Source: Mijatović, B. (2017). Siromaštvo u Republici Srbiji 2006-2016. godine, Beograd: Tim za socijalno uključivanje i smanjenje siromaštva Vlade Srbije.

Since poverty rates are obtained on the basis of a sample, and not on the basis of an entire population survey, they are discussed with a certain probability. With a probability of $95 \%$ it can be argued that the poverty rate in 2016 to be surveyed by the entire population is in the range of $6.3 \%$ to $8.3 \%$, i.e. with this probability it can be argued that the absolutely poor were between $6.3 \%$ and $8.3 \%$ (Mijatović, 2017). Compared to 2006, with a probability of $95 \%$, it can be argued that a significant decline occurred in 2008 and 2012 (the years when there was no overlap of the 
confidence interval), while for the rest of the years there were statistically significant changes in the volume of poverty. Data on the poverty depth(intensity) show how much it is below the poverty line. This measures the poverty deficit of the entire population and shows how much resources it takes, under the assumption of perfect targeting, that poverty is completely eliminated. In the observed period there is a constant decrease in the depth of poverty. At the same time, there is also a reduction in the poverty gap (a measure that expresses inequality among the poor, giving greater weight to the poorest).

\section{Research on the dependence of economic growth and the rate of poverty}

\subsection{Research methodology}

The subject of the research is to determine the mutual dependence of economic growth and the poverty rate in the Republic of Serbia. For identifying statistical mass, sampling, data collection and analysis of the results, statistical-econometric models are applied which correspond to the defined object and purpose of the research, but also to the selected variables. Part of the data analysis was carried out on data collected through the Survey on Income and Living Conditions (EU-SILC). It is an instrument that is among the most relevant when it comes to monitoring poverty, inequality, social inclusion and living standards. In addition to the data collected by the "Survey on Income and Living Conditions" (EU-SILC), the data that were obtained electronically - by downloading publicly available databases of national statistical institutions were also used in this paper.

The study starts from the following hypothesis:

1. The greater the economic growth of the Republic of Serbia, the lower the poverty rate.

2. The lower the economic activity, the greater the decline in the standard of living of the population.

3. The economic growth followed by an increase in the share of the poor in the distribution of income is higher, the greater the opportunities for the incomes of this category of population to grow faster.

To prove the hypothesis, a Hi-square method was used to test the differences between the observed andthe expected frequencies. The Hi-square includes proportions and probability provided that they are transformed into absolute frequencies. The correlation coefficient, which is a measure of the joint variation of two or more variables and the degree of their interconnection, was also used to indicate whether there is a connection between variables, as well as the quality of connectivity. It will be positive if the increase in the measure of one variable is accompanied by an increase in the measures of the other. A negative relationship 
exists if the increase in the measure of one variable is accompanied by a decrease in the measures of the other. Before the coefficient of correlation, regression analysis was also used.

\subsection{Results of the research}

Based on the statistical data obtained in the survey, that is, taken from the base of the Republic Bureau of Statistics, the rate of real GDP growth and the poverty rate will be used for the parameters of economic growth.

The obtained results show that the total gross domestic product in Serbia in the period from 2008 to 2017 was mainly recorded (with the exception of 2009 and 2014, when the growth rate was negative). In the same period, there can be no significant reduction in the poverty rate. In the last observed $2016,7.3 \%$ of the population is absolutely poor, while the decrease in the absolute number of the poor is primarily a result of a decrease in the number of inhabitants.

\begin{tabular}{|c|c|c|c|}
\hline \multicolumn{4}{|c|}{ Correlations } \\
\hline & & Gdp & poverty \\
\hline \multirow[t]{3}{*}{$\overline{\text { Gdp }}$} & $\begin{array}{l}\text { Pearson } \\
\text { Correlation }\end{array}$ & 1 &,- 157 \\
\hline & $\begin{array}{l}\text { Sig. } \\
\text { tailed) }\end{array}$ & & ,686 \\
\hline & $\mathrm{N}$ & 9 & 9 \\
\hline \multirow[t]{3}{*}{ poverty } & $\begin{array}{l}\text { Pearson } \\
\text { Correlation }\end{array}$ &,- 157 & 1 \\
\hline & $\begin{array}{l}\text { Sig. } \\
\text { tailed) }\end{array}$ & ,686 & \\
\hline & $\mathrm{N}$ & 9 & 9 \\
\hline
\end{tabular}

Case Processing Summary

\begin{tabular}{|c|c|c|c|c|c|c|}
\hline & \multicolumn{6}{|c|}{ Cases } \\
\hline & \multicolumn{2}{|c|}{ Valid } & \multicolumn{2}{|c|}{ Missing } & \multicolumn{2}{|c|}{ Total } \\
\hline & $\mathrm{N}$ & Percent & $\mathrm{N}$ & Percent & $\mathrm{N}$ & Percent \\
\hline $\begin{array}{l}\text { gdp } \\
\text { poverty }\end{array}$ & 9 & $100,0 \%$ & 0 & $0,0 \%$ & 9 & $100,0 \%$ \\
\hline
\end{tabular}




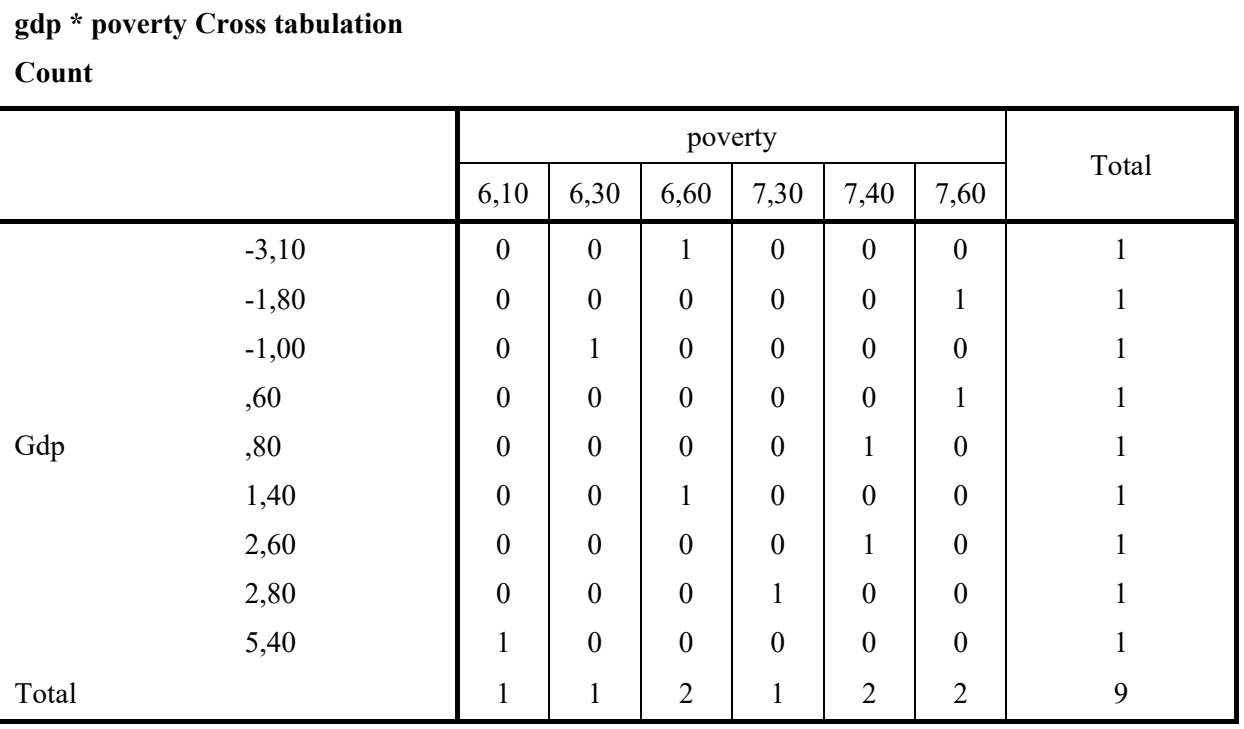

Chi-Square Tests

\begin{tabular}{|l|c|c|c|}
\hline & Value & df & Asymp. Sig. (2-sided) \\
\hline $\begin{array}{l}\text { Pearson } \\
\text { Chi-Square }\end{array}$ & $45,000^{\mathrm{a}}$ & 40 &, 271 \\
$\begin{array}{l}\text { Likelihood } \\
\text { Ratio }\end{array}$ & 31,232 & 40 &, 838 \\
$\begin{array}{l}\text { Linear-by- } \\
\text { Linear } \\
\text { Association }\end{array}$ &, 198 & 1 &, 657 \\
$\begin{array}{l}\text { N of Valid } \\
\text { Cases }\end{array}$ & 9 & \\
\hline
\end{tabular}

a. 54 cells $(100,0 \%)$ have expected count less than 5 . The minimum expected count is, 11 .

Hi-square $=45$

$\mathrm{Df}=40$--- degrees of freedom

$p=0.271$--- since $p>0.05$, we conclude that there is no statistically significant dependence between the values of these two variables. 
Pearson's correlation coefficient also showed that there was no statistically significant correlation.

Based on the data, it can be concluded that the First Hypothesis was denied because in the observed years the poverty rate did not decrease, although gross domestic product recorded growth. For the verification of the second hypothesis, based on the statistical data obtained in the survey, that is, taken from the base of the Republic Institute for Statistics, the average net monthly salary per employee and the average consumer basket will be used as parameters.

\begin{tabular}{|c|c|c|c|c|c|c|c|c|c|}
\hline & 2008. & 2009. & 2010. & 2011. & 2012. & 2013. & 2014. & 2015. & 2016. \\
\hline $\begin{array}{c}\text { Average } \\
\text { net salary } \\
\text { per } \\
\text { employe } \\
\text { (din) }\end{array}$ & 32757 & 31758 & 34159 & 38017 & 41386 & 43944 & 44525 & 44437 & 46087 \\
\hline $\begin{array}{c}\text { Average } \\
\text { consumer } \\
\text { basket } \\
\text { (din) }\end{array}$ & 43904 & 47444 & 50138 & 55568 & 59593 & 64895 & 66013 & 66903 & 67437 \\
\hline
\end{tabular}

\section{Correlations}

\begin{tabular}{|c|c|c|c|}
\hline & AverageNetSalary & AverageConsumerBasket \\
\hline AverageNetSalary & $\begin{array}{l}\text { Pearson } \\
\text { Correlation } \\
\text { Sig. (2- } \\
\text { tailed) } \\
\mathrm{N}\end{array}$ & 1 &, $986^{* *}$ \\
& $\begin{array}{l}\text { Pearson } \\
\text { Correlation } \\
\text { Sig. (2- } \\
\text { tailed) } \\
\text { AverageConsumerBasket }\end{array}$ &, $986^{* *}$ & 9 \\
$\mathrm{~N}$ &, 000 & 1 \\
\hline
\end{tabular}

**. Correlation is significant at the 0.01 level (2-tailed). 
Model Summary

\begin{tabular}{|c|c|c|c|c|}
\hline $\begin{array}{c}\text { Mode } \\
1\end{array}$ & $\mathrm{R}$ & R Square & Adjusted R Square & $\begin{array}{c}\text { Std. Error of the } \\
\text { Estimate }\end{array}$ \\
\hline 1 &, $986^{\mathrm{a}}$ &, 972 &, 968 & 998,96660 \\
\hline
\end{tabular}

a. Predictors: (Constant), AverageConsumerBasket

\begin{tabular}{|c|c|c|c|c|c|c|}
\hline \multicolumn{7}{|c|}{ ANOVA $^{a}$} \\
\hline \multicolumn{2}{|c|}{ Model } & Sum of Squares & Df & Mean Square & $\mathrm{F}$ & Sig. \\
\hline \multirow{3}{*}{1} & Regression & 245192060,383 & 1 & 245192060,383 & 245,700 & $\underset{\mathrm{b}}{, 000}$ \\
\hline & Residual & 6985539,840 & 7 & 997934,263 & & \\
\hline & Total & 252177600,222 & 8 & & & \\
\hline
\end{tabular}

a. Dependent Variable: AverageNetSalary

b. Predictors: ConstantAverageConsumerBasket

Coefficients $^{\mathrm{a}}$

\begin{tabular}{|c|c|c|c|c|c|c|}
\hline \multirow{2}{*}{ Model } & & \multicolumn{2}{|c|}{$\begin{array}{l}\text { Unstandardized } \\
\text { Coefficients }\end{array}$} & \multirow{2}{*}{$\begin{array}{c}\begin{array}{c}\text { Standardized } \\
\text { Coefficients }\end{array} \\
\text { Beta }\end{array}$} & \multirow[t]{2}{*}{$\mathrm{t}$} & \multirow{2}{*}{ Sig. } \\
\hline & & B & Std. Error & & & \\
\hline \multirow{2}{*}{1} & (Constant) & 4342,200 & 2278,541 & & 1,906 & ,098 \\
\hline & AverageConsumerBasket & 609 & ,039 & ,986 & 15,675 &, 000 \\
\hline
\end{tabular}

a. Dependent Variable: AverageNetSalary

The correlation coefficient is shown in the first table and it shows the significance $r<0.05$, so the correlation between the variables is statistically significant. This value is marked in green, and the value of the coefficient itself is red.

The results of the regression analysis are shown in the previous tables. The above table gives the significance of the whole model, and the lower one significance of the coefficients, how is the model: $y=a+b x$, $a$ is a Const., and $b$ is our independent variable.

The results of the regression analysis show that there is dependence between the variables, that is, the formed regression model is statistically significant. Based on the data, it can be concluded that the Second Hypothesis is fully proven because there is dependence between the analyzed variables. 
For the verification of the third hypothesis, based on the statistical data obtained in the survey, that is, taken from the base of the Republic Institute for Statistics, for indicators of poverty, the chain indexes of real average net wages represent the ratio between the indexes of nominal average net wages and the consumer price index. Inequality in the distribution of income is the general characteristic of all societies. The main indicators of inequality are: household decisions per deciles and the Gini coefficient.

In Serbia, $10 \%$ of the richest households earn 10 times more income than $10 \%$ of the poorest. The percentage of the poor in a given country is calculated on the basis of the poverty line. The poverty line includes food expenditure as well as expenditure on clothing, footwear, hygiene and furniture, health services and education. The basic source of data on poverty in Serbia is the Living Standards Survey.

Gini coefficient measures inequality throughout the distribution of income / consumption. It takes values from 0 to 1 (or 100, depending on the record), where 0 represents a completely equal distribution of income / consumption, and 100 completely unequal distribution of income / consumption.

The available net household income is the starting aggregate for the analysis of inequality, and it includes cash income from labour, income from ownership, pensions, social and other transfers received by the household from nonhouseholds. This is the income that, after paid taxes and contributions, is available to the household for consumption and savings. One way of allocating the total household income to its members is the sharing of household income with the number of household members. Thus, per capita income is earned, and this means that all household members are entitled to an equal share of that household resources. However, this is not adequate because different individuals need a different amount of resources to reach the same level of well-being. Two important facts that are neglected when sharing the same amount of income for all household members are: the difference in consumption among adults and children and the economies of scale, or the fact that some expenditure is shared among household members (living expenses, car use, and daily press and similarly).

The quantile ratio is calculated as the ratio of total income received by $20 \%$ of the population with the highest income and total income that receives $20 \%$ of the population with the lowest income. The ratio of the share ofincometo $20 \%$ of the population with the highest and $20 \%$ of the lowest-earning population is the highest in Serbia in relation to all other countries in which the life standard survey is conducted. Twenty percent of the richest population in Serbia has 9.7 times higher income than $20 \%$ of the lowest-income population.

In order to verify the third hypothesis, on the basis of the statistical data obtained in the research, which is, taken from the base of the Republic Statistical Office, the relations between the Gini coefficient and the quantile relationship will be used. 
Veselinović et al. / Economic Themes, 57(3): 287-305

\begin{tabular}{|c|c|c|c|c|c|c|c|c|c||}
\hline & 2008. & 2009. & 2010. & 2011. & 2012. & 2013. & 2014. & 2015. & 2016. \\
\hline $\begin{array}{c}\text { Gini } \\
\text { coefficient }\end{array}$ & 32,1 & 31,2 & 33,0 & 38,0 & 38,7 & 38,0 & 38,6 & 38,2 & 38,6 \\
\hline $\begin{array}{c}\text { Quantile } \\
\text { ratio }\end{array}$ & 7,8 & 7,7 & 7,9 & 9,1 & 8,8 & 8,6 & 9,8 & 9,0 & 9,7 \\
\hline \hline
\end{tabular}

The obtained results of the correlation coefficient are shown in the following table:

\begin{tabular}{|c|c|c|c|}
\hline & & GINI & QuantileRatio \\
\hline \multirow{3}{*}{ GINI } & $\begin{array}{l}\text { Pearson } \\
\text { Correlation }\end{array}$ & 1 &, $889^{* *}$ \\
\hline & Sig. (2-tailed) & &, 001 \\
\hline & $\mathrm{N}$ & 9 & 9 \\
\hline \multirow{3}{*}{ QuantileRatio } & $\begin{array}{l}\text { Pearson } \\
\text { Correlation }\end{array}$ &, $889^{* *}$ & 1 \\
\hline & Sig. (2-tailed) &, 001 & \\
\hline & $\mathrm{N}$ & 9 & 9 \\
\hline
\end{tabular}

**. Correlation is significant at the 0.01 level (2-tailed).

The correlation coefficient is shown in the first table and it shows the significance $r<0.05$, so the correlation between the variables is statistically significant.

Model Summary
\begin{tabular}{|c|c|c|c|c|}
\hline Model & $\mathrm{R}$ & $\begin{array}{c}\mathrm{R} \\
\text { Square }\end{array}$ & $\begin{array}{c}\text { Adjusted R } \\
\text { Square }\end{array}$ & $\begin{array}{c}\text { Std. Error of the } \\
\text { Estimate }\end{array}$ \\
\hline 1 &, $889^{\mathrm{a}}$ &, 790 &, 760 & 1,55331 \\
\hline
\end{tabular}

a. Predictors: (ConstantQuantileRatio

ANOVA $^{\mathrm{a}}$

\begin{tabular}{|c|c|c|c|c|c|c|}
\hline \multicolumn{2}{|c|}{ Model } & $\begin{array}{c}\text { Sum of } \\
\text { Squares }\end{array}$ & $\mathrm{df}$ & Mean Square & F & Sig. \\
\hline \multirow{3}{*}{1} & Regression & 63,371 & 1 & \multirow{3}{*}{$\begin{array}{l}63,371 \\
2,413\end{array}$} & \multirow[t]{3}{*}{26,265} & \multirow[t]{3}{*}{, $001^{\mathrm{b}}$} \\
\hline & Residual & 16,889 & 7 & & & \\
\hline & Total & 80,260 & 8 & & & \\
\hline
\end{tabular}


a. Dependent Variable: GINI

b. Predictors: (Constant), QuantileRatio

Coefficients $^{\mathrm{a}}$

\begin{tabular}{|c|c|c|c|c|c|}
\hline \multirow[t]{2}{*}{ Model } & \multicolumn{2}{|c|}{$\begin{array}{l}\text { Unstandardized } \\
\text { Coefficients }\end{array}$} & \multirow{2}{*}{$\begin{array}{c}\begin{array}{c}\text { Standardized } \\
\text { Coefficients }\end{array} \\
\text { Beta }\end{array}$} & \multirow[t]{2}{*}{$\mathrm{t}$} & \multirow[t]{2}{*}{ Sig. } \\
\hline & B & Std. Error & & & \\
\hline (Constant) & 5,032 & 6,117 & & 823 & ,438 \\
\hline QuantileRatio & 3,586 & ,700 & 889 & 5,125 & 001 \\
\hline
\end{tabular}

a. Dependent Variable: GINI

The results of the regression analysis are shown in the previous tables. The above table gives the significance of the whole model, and the lower significance of the coefficients, how is the model: $y=a+b x$, $a$ isa constant, and $b$ is our independent variable. The results of the regression analysis show that there is dependence between the variables, that is, the formed regression model is statistically significant. On the basis of the data, it can be concluded that the third hypothesis is fully proven because there is dependence between the analyzed variables.

\section{Conclusion}

With the liberalization of economic activities, during transition, an increase in income inequality should be expected, primarily under the influence of changes in the distribution of salaries. Given the current situation in the period of socialism, a certain increase in inequality is logical and justified, as it contributes to the improvement of economic efficiency, which is crucial for the success of reforms. It is important, however, that changes in inequality are kept under control and that they are carefully managed. The situation and the pace of these changes cannot be completely left to the liberated market forces. Acceptable income distribution is one of the most important long-term goals of society. It is expected from transition to improve the standard of living of most inhabitants. Otherwise, the whole process would not make much sense.

High inequality diminishes the effect that the data rate of growth has on the suppression of poverty. In addition, it undermines the possibilities of addressing the poverty problem, reducing the rate of economic growth. Contrary to earlier beliefs that higher income inequalities favor economic growth, recent research 
shows that a more even distribution of income through various channels can act as an effective growth stimulator. Thus, economic reforms are reflecting on the trend of poverty, but poverty, in turn, is a sign of economic reforms. The fact that Serbia had, and still has, a significant number of the poor, but also those living close to the poverty line, cannot be ignored in conceiving reforms. The social dimension of transition must be kept in mind.

The specificity of Serbia lies in the fact that the population paid a high social price even before the serious transition to the transition process. The social consequences, everything that happened in the nineties of the twentieth century, are very similar to the social consequences of market transformation that have emerged in other former socialist countries. These consequences include: impoverishment of the population, decline in employment, unemployment, lowering the level of public services, social exclusion, deterioration of population health, etc.

\section{References}

Begović, B., Matković, G., Mijatović, B., Popović, D. (2009).Od siromaštva ka prosperitetu: Tržišna rešenja za privredni rast, Beograd: Službeni glasnik.

Blanchard, O. (2007).The Economics of Post-CommunistTransition, Oxford: ClarendonPress.

Cerović, B. (2003).Ekonomika tranzicije, Beograd: Ekonomski fakultet.

Costa A. B. (2006). The measurement of poverty, Journal of EuropeanSocialPolicy, 4(2), 92-103.

Devetaković, S., Jovanović Gavrilović, B., Rikalović, G. (2008).Nacionalna ekonomija, Beograd: Ekonomski fakultet.

Dollar D., Kraay A. (2010).Growth is Good for the Poor, WorldBank, Washington.

Đorđević, M., Obradović, S. (2012).Osnovi makroekonomije, Kragujevac: Ekonomski fakultet.

Džunić M., Golubović N. (2018) Educational Attainment, Poverty and Social Exclusion: the Case of Serbia, In: Krstić, B. (ed) Crucial Aspects of Improving National Competitiveness, pp. 71-87, Niš: Faculty of Economics,.

Gligorijević, Ž. Aranđelović, Z. (2008) Regionalna ekonomija, Niš: Ekonomski fakultet.

Mijatović, B. (2017).Siromaštvo u Republici Srbiji 2006-2016. godine, Beograd: Tim za socijalno uključivanje i smanjenje siromaštva Vlade Srbije.

Silver, H. (2004).Social exclusion and solidarity: Three paradigms, International Labour Review, 133(5-6), 56-57.

Townsend, P. (2010).The concept of poverty, London: Heinemann.

Veselinović, P. (2013). Nacionalna ekonomija, Kragujevac: Ekonomski fakultet. 


\section{UTICAJ EKONOMSKIH REFORMI NA SIROMAŠTVO U REPUBLICI SRBIJI}

Rezime: Cilj ovog rada je da identifikauje ključne determinante siromaštva u Republici Srbiji. Sekundarni cilj je pokazati da se siromaštvo može smanjiti ako se napusti klasični koncept tretiranja siromaštva i prihvati koncept socijalne isključenosti, čija je korist sagledavanje uzroka i stvaranje osnova za sprečavanje problema siromaštva, a ne samo pokušaj da otkloni posledice. U radu su primenjeni statističko-ekonometrijski modeli koji odgovaraju definisanom cilju empirijskog istraživanja, ali i odabranim varijablama. Deo analize podataka izvršen je na podacima prikupljenim kroz Anketu o prihodima i životnim uslovima (EU-SILC). To je instrument koji je među najrelevantnijim kada je u pitanju praćenje siromaštva, nejednakosti, socijalne uključenosti i životnog standarda. Doprinos rada ogleda se u razvoju istraživanja siromaštva u Republici Srbiji, sa ciljem da se dopuni fond naučnih saznanja o primeni državnih mera i instrumenata u kontekstu podsticanja ekonomskog rasta i povećanja životnog standarda stanovništva

Ključne reči: tranzicija, siromaštvo, životni standard, Republika Srbija

\section{Authors' biographies}

Nevena Veselinović was born on September 5, 1992 in Kragujevac. Faculty of Economics, University of Kragujevac, she enrolled in the 2011/2012 school year at the study program Economics, module Finance, Stock Exchanges and Bankinga and graduated on October 09, 2015, with an average grade of 9.03. Master Studies, at the Faculty of Economics, University of Kragujevac, program Economics (module Finance, Stock Exchanges and Banking), she enrolled in the academic year 2015/2016 and defended her master's thesis entitled Operational Risk Management in the Banking and Insurance Sector on 2016. Doctoral studies, in the study program Economics (module Macroeconomics), she enrolled in the academic year 2017/2018. Since August 7, 2018, she has been employed at the Faculty of Management in Zajecar as an associate researcher funded by the Ministry of Education, Science and Technological Development, until the end of the current Project cycle. She is a member of the Kragujevac Society of economists.

Ivan Mišić was born on June 16, 1968 in Kragujevac. He graduated from the Army Academy in Belgrade in 1991. He completed his postgraduate studies (School of National Defense) for two years also in Belgrade in 2005. In his working career, he served in the Military Police Units on command posts from 1991 to 2003 in Nis, Kragujevac and Belgrade, then in charge of the Army of Serbia Guard until 2012, and now works in the General Staff Planning and Development Directorate Serbian Armed Forces. He attended a number of advanced training courses as required by the Military Service. As part of his advanced training, he enrolled in doctoral studies at the Faculty of Applied Management, Economics and Finance MEF in Belgrade. He has published several professional papers in economics and financial analysis. $\mathrm{He}$ is a member of the Organizing Committee of multidisciplinary TQM international conferences in Zrenjanin. 
Petar Veselinović is a full professor at the Faculty of Economics, University of Kragujevac, where he teaches Theory and Analysis of Economic Policy and National Economics at the Department of General Economics and Economic Development. In his scientific career, he has published 169 scientific papers, 4 textbooks and 2 monographs. In order to further his scientific and professional development, he attended the University of Economics in Krakow and the Guglielmo Marconi University in Rome. He has been involved in a number of research projects. In his rich career at the Faculty of Economics, University of Kragujevac, he served as the Vice-Dean for Teaching and Student Affairs, the Vice-Dean for Scientific Research, the Director of the Center for Economic Research, and since September 2016 he has been the Dean of the Faculty. From December 2015 to September 2016, he served as Vice-Rector for Teaching and Student Affairs at the University of Kragujevac. In addition to university involvement, he is also actively engaged in the wider community. He was a member of the City Council for economic policy and finance of the City of Kragujevac, coordinator of the Local anti-corruption forum of the City of Kragujevac, Chairman of the board of the University library, president of the board of directors of FK "Radnicki 1923" and member of the board of directors: Red Cross of the City of Kragujevac, Fund "Prof . Ilija Rosić, PhD, and the Ekonomac Small Football Club. He has been a member of the Presidency of the Association of Serbian economists since 2015. At the founding assembly, held on February 25, 2015, he was elected president of the Kragujevac Society of economists. 